\title{
Analisis Stabilitas Dan Keamanan Bendungan Ciawi (dry dam) Di Provinsi Jawa Barat
}

\author{
Lia Maretha ${ }^{1}$, Suseno Darsono ${ }^{2}$, Kresno Wikan Sadono ${ }^{2}$ \\ Mahasiswa Program Magister Teknik Sipil, Fakultas Teknik, Universitas Diponegoro, Semarang ${ }^{1}$ \\ Magister Teknik Sipil, Fakultas Teknik, Universitas Diponegoro, Semarang ${ }^{2}$ \\ Email : liamaretha@student.undip.ac.id ${ }^{1}$, sdarsono@ hotmail.com ${ }^{2}$, kresnowikan@ gmail.com ${ }^{2}$
} DOI: http://dx.doi.org/10.31869/rtj.v3i2.1793

\begin{abstract}
Abstrak: Bendungan Ciawi merupakan bendungan kering (dry dam) pertama di Indonesia yang memiliki fungsi utama sebagai pengendali banjir (detention dam) dan merupakan program pemerintah dalam penanggulangan banjir di DKI Jakarta. Bendungan Ciawi dibangun dengan konsep dry dam yaitu pada saat kondisi normal bendungan Ciawi tidak memiliki tampungan air dan saat banjir bendungan akan menampung dan kemudian akan mengalirkan melalui saluran conduit dengan diameter $4.2 \mathrm{~m}$. Bendungan urugan memiliki resiko mengalami kegagalan, maka hal penting yang perlu menjadi perhatian yaitu stabilitas lereng pada bendungan. Ciawi Dry Dam memiliki kapasitas 6,05 juta $\mathrm{m}^{3}$ dengan tinggi $55 \mathrm{~m}$ dan masuk dalam klasifikasi IV (extrem) atau memiliki resiko bahaya yang tinggi jika terjadi kegagalan, penelitian ini bertujuan untuk mengetahui nilai faktor keamanan (FK) dari berbagai kondisi pada lereng Bendungan Ciawi. Metode yang digunakan adalah metode kualitatif dan metode analisis data secara kuantitatif meliputi pemetaan geologi dan geologi teknik, serta analisis kestabilan lereng dengan bantuan perangkat lunak GeoStudio 2012 Slope/W. Perhitungan nilai Faktor Keamanan (FK) dilakukan pada tiga kondisi yaitu kondisi selesai konstruksi, muka air normal dan rapid drawdown. Dari hasil perhitungan pada kondisi tanpa gempa dan gempa Operation Base Earthquake (OBE) nilai FK telah memenuhi syarat minimum berdasarkan SNI 8064:2016.
\end{abstract}

Kata Kunci : Bendungan Ciawi, Dry Dam, Stabilitas Lereng, GeoStudio, Slope/W.

\section{PENDAHULUAN}

Bendungan Ciawi merupakan bendungan urugan tanah yang dibangun dengan konsep dry dam atau bendungan kering pertama di Indonesia yang memiliki fungsi utama sebagai detension dam atau pengendali banjir. Detention dam yaitu bendungan yang dibangun untuk memperlambat aliran air sehingga dapat mencegah terjadinya banjir besar (Soedibyo, 2003). Bendungan memiliki banyak manfaat yang sangat berguna bagi kelangsungan hidup masyarakat dihilirnya, namun bendungan juga menyimpan resiko yang tinggi yaitu berupa kemungkinan terjadinya kegagalan atau runtuhnya bendungan. Kestabilan lereng merupakan salah satu faktor utama dalam keamanan bendungan urugan. Berdasarkan hal tersebut, perlu dilakukan analisis kestabilan lereng pada tubuh lereng Bendungan Ciawi agar bendungan tersebut tidak mengalami kegagalan bendungan.

Terdapat beberapa tujuan dari penelitian ini. Pertama, untuk mengetahui kondisi geologi dan geologi teknik pada wilayah tempat dibangunnya Bendungan Ciawi. Kedua, Mengetahui karakteristik zona tipikal dan material timbunan tubuh bendungan pada Bendungan Ciawi. Ketiga, Mengetahui faktor keamanan lereng tubuh Bendungan Ciawi pada kondisi selesai konstruksi, muka air normal, dan rapid drawdown.

Secara administratif, Bendungan Ciawi terletak di Desa Cipayung, Kecamatan Megamendung, Kabupaten Bogor, Jawa Barat. Secara geografis, koordinat dari tubuh Bendungan Ciawi terletak pada koordinat $106^{\circ}$ 52' 46" BT, 6 39' 34’'LS.

\section{METODE PENELITIAN}

Metode yang dilakukan untuk melakukan analisis kestabilan lereng yaitu metode irisan bidang luncur cara Simplified Bishop dengan bantuan perangkat lunak GeoStudio 2012 Slope/W. Perhitungan Faktor Keamanan (FK) dilakukan pada tiga kondisi yaitu kondisi selesai konstruksi, muka air normal, dan rapid drawdown sehingga menghasilkan 54 buah nilai FK.. 


\section{Analisis Beban Gempa}

Analisis beban gempa yang digunakan dalam perencanaan suatu bangunan yang dapat menahan gempa diklasifikasikan menjadi dua macam, yaitu analisis secara statik dan dinamik (Chopra, 1995). Goncangan gempa untuk desain sebuah bendungan harus mencakup goncangan dengan mempertimbangkan kodisi beban tanah yang tidak biasa disebut dengan Operationing Basis Earthquake (OBE) dan gempa desain maksimum Maximum Design Earthquake (MDE) mempertimbangkan beban pada kondisi ekstrim, yang kemudian dikombinasikan dengan beban yang diperkirakan ada selama masa operasi rutin Bendungan (Tanjung et al., 2018).

Koefisien gempa yang diuraikan dalam Pedoman Analisis Stabilitas Bendungan Tipe Urugan Akibat Beban Gempa (Departemen Pemukiman Dan Prasarana Wilayah, 2004), perlu untuk dilakukan modifikasi dengan metode yang telah dikembangkan oleh negara Jepang yaitu meode "Seismic Design Guadeline For Fill Dam" (Fata \& Suhartanto, 2018). Untuk metode analisis yang digunakan dapat diketahui berdasarkan kriteria beban gempa dari hasil kelas risiko yang telah didapatkan, kemudian dilakukan analisis koefisien gempa dengan periode kala ulang tertentu. Perhitungan koefisien gempa menggunakan Persamaan 1 hingga persamaan 6.

$\mathrm{PGA}_{\mathrm{M}}=\mathrm{F}_{\mathrm{PGA}} \times \mathrm{S}_{\mathrm{B}}$

$\mathrm{K}_{\mathrm{h}} \quad=\mathrm{PGA}_{\mathrm{M}} / \mathrm{g}$

$\mathrm{K}_{\mathrm{o}} \quad=\alpha_{2} \times \mathrm{K}_{\mathrm{h}}$

Keterangan:

$\mathrm{PGA}_{\mathrm{M}}$ : Percepatan gempa terkoreksi.

$\mathrm{F}_{\mathrm{PGA}} \quad$ : Faktor amplifikasi untuk PGA

$\mathrm{S}_{\mathrm{B}} \quad$ : Nilai percepatan gempa dasar

dari peta Gempa 2010

g : Kecepatan gravitasi bumi

$\mathrm{K}_{\mathrm{h}} \quad$ : Koefisien gempa horisontal pada periode $\mathrm{T}$.

$\alpha_{2} \quad$ : Koreksi pengaruh struktur. untuk bendungan urugan $=0,5$.

$\mathrm{K}_{\mathrm{o}} \quad$ : Koefisien gempa terkoreksi di permukaan tanah.

Nilai koefisien gempa pada kedalaman Y dari puncak bendungan berbeda-beda. Hal ini dikarenakan apabila semakin tinggi tempat yang ditinjau, maka guncangan gempa akan semakin besar. Perhitungan dilakukan pada Y/H 0,25;0,5;0,75; dan 1 (Imron et al., 2017).

Untuk $0<\mathrm{Y} / \mathrm{H} \leq 0,4$

$\begin{aligned} \mathrm{K}_{\mathrm{h}}= & \mathrm{K}_{\mathrm{o}} \quad(2,5 \quad-\quad 1,85 \quad \mathrm{x} \quad(\mathrm{Y} / \\ & \mathrm{H})) \ldots \ldots \ldots \ldots \ldots . .(4) \\ \text { Untuk } & 0,4<\mathrm{Y} / \mathrm{H} \leq 1,0 \\ \mathrm{~K}_{\mathrm{h}}= & \mathrm{K}_{\mathrm{o}} \quad(2 \quad-\quad 0,60 \quad \mathrm{x} \quad(\mathrm{Y} / \\ & \mathrm{H})) \ldots \ldots \ldots \ldots \ldots . .(5)\end{aligned}$

Keterangan:

$\mathrm{K}_{\mathrm{h}}$ : Koefisien gempa pada kedalaman Y dari puncak bendungan

$\mathrm{K}_{\mathrm{o}}$ : Koefisien gempa terkoreksi di permukaan tanah

Hasil perhitungan tersebut akan didapatkan nilai Kh (Koefisien Horizontal) pada Y/H dengan periode ulang ( $\mathrm{T}$ ) yang diinginkan. Kemudian dari hasil tersebut, dapat dihitung Kv (Koefisien Vertikal) dengan persamaan berikut:

$\mathrm{Kv}=0,6 \mathrm{Kh}$.

Keterangan :

$\mathrm{Kv}:$ Koefisien gempa vertikal

$\mathrm{Kh}$ : Koefisien gempa horizontal

Gempa desain maksimum (MDE) adalah gempa yang memberikan getaran paling besar pada daerah penelitian. Gempa dasar operasi (OBE) adalah batasan getaran gempa pada daerah penelitian dengan $50 \%$ kemungkinan gempa tidak terlampau dalam 100 tahun.

\section{Analisa Stabilitas lereng}

Longsorang yang terjadi pada bendungan sangat berbahaya untuk keamanan bendungan urugan, longsoran yang terjadi biasanya berbentuk lingkaran. Untuk analisa longsorang dengan bentuk lingkaran digunakan metode keseimbangan gaya atau metode keseimbangan momen (Dharmayasa et al., 2017). Dalam análisis stabilitas lereng bendungan membutuhkan perhitungan kuat geser material sepanjang permukaan yang berpotensi terjadi runtuh. Berdasarkan kriteria keruntuhan Mohr-Coloumb dengan konsep tegangan efektif, maka kuat geser "S"(pada saat terjadi runtuh) dapat dirumuskan sebagai berikut (Direktorat Jenderal Sumber Daya Air, 2003) :

$S^{\prime}=c^{\prime}+(\sigma-\mu) \tan \emptyset$

Dimana :

$S=$ kekuatan geser efektif $\left(\mathrm{t} / \mathrm{m}^{2}\right)$

$c^{x}=$ kohesi efektif $\left(\mathrm{t} / \mathrm{m}^{2}\right)$

$\sigma=$ tegangan normal total $\left(\mathrm{t} / \mathrm{m}^{2}\right)$ 
$\mu=$ tekanan air pori

$\emptyset=$ sudut geser dalam efektif $\left(^{\circ}\right)$

Hasil análisis dinyatakan dalam nilai faktor keamanan (FK) yang dinyatakan sebagai berikut :

$F=\frac{s}{\tau}=\frac{\text { Kust Geser (Shear Strenght) }}{\text { Tegangan Geser (Shear Stress) }}$

Dengan

$\mathrm{FK}=\frac{S}{\tau} \geq 1$ atau $\mathrm{S}>\tau=$ aman $\mathrm{S}<\tau=$ tidak stabil.

Tabel 1. Persyaratan FK minimum lereng bendungan tipe urugan berdasarkan (SNI 8064-2016)

\section{FK Syarat}

No

Kondisi
Kondisi stabilitas pada lereng hulu (upstream) dan lereng hilir (downsream) pada bendungan urugan pada umumnya analisis dilakukan pada kondisi yang paling kritis yang mungkin terjadi yaitu pada saat akhir konstruksi, muka air normal (steady state seepage), surut cepat (rapid drawdown) dan earthquake (pseudostatic analysis) (Nanda \& Hamdhan, 2016). Standar nilai Faktor Keamanan (FK) yang digunakan merujuk pada SNI 80642016, (Tabel 1).

$\begin{array}{ccc}\text { anpa Beban } & \begin{array}{c}\text { Dengan Beban } \\ \text { Gempa }\end{array} & \begin{array}{c}\text { Dengan Beban } \\ \text { Gempa MDE }\end{array}\end{array}$

\begin{tabular}{lllll}
\hline 1 & Selesai Konstruksi & 1.3 & 1.2 & 1 \\
\hline 2 & Muka Air Normal & 1.5 & 1.2 & 1 \\
\hline 3 & Rapid Drawdown & 1.3 & - & - \\
\hline
\end{tabular}

HASIL DAN PEMBAHASAN

Berdasarkan Peta Geologi Regional tahun 2010 lembar Bogor lokasi bendungan Ciawi (Dry am) terletak di zona Bogor tertutup oleh batuan vulkanik muda hasil erupsi gunung api pada zaman Plistosen atau terinjeksikan lewat zona-zona sesar pada sedimen Miosen. Hasil pemetaan geologi di daerah dam site memiliki sifat fisik-mekanik dan kesesuaian bentuk topografi terutama untuk lapisan penutup (unconsolidated deposit), daerah penelitian terbagi atas tujuh satuan batuan, adapun urutan dari tua ke muda dapat dijelaskan sebagai berikut :

1. Satuan Batuan Breaksi Tuff

Satuan breksi tuff merupakan batuan dasar yang termasuk dalam batuan vulkanik kuarter, yang penyebarannya dari sandaran kiri bendungan, dasar sungai sampai sandaran kanan bendungan. Breksi tuff berwarna abu-abu hingga abu-abu kecoklatan dan berada dalam batuan lapuk sedang dapat dilihat pada gambar 1 .

2. Satuan Batuan Aglomerate

Satuan Aglomerate termasuk dalam kelompok batuan vulkanik kuarter. Batuan ini terdapat di sandaran kanan bendungan pada kedalaman $17 \mathrm{~m}$. Satuan batuan aglomerate berwarna abu hingga abu-abu kecoklatan, lapuk sedang, dan kekerasan sedang.

3. Satuan Batuan Tuff Lapili

Satuan batuan tuff lapili termasuk dalam kelompok batuan vulkanik kuarter. Penyebarannya berada di sandaran kiri bendungan, dasar sungai dan sandaran kanan bendungan, pada umumnya berwarna abu-abu hingga coklat tua dalam kondisi lapuk kuat sampai lapuk sedang dapat dilihat pada gambar 1

4. Satuan Batuan Tuff

Satuan tuff termasuk dalam kelompok batuan vulkanik kuarter. Batuan ini terdapat di dasar sungai pada kedalaman 25 $\mathrm{m}$ dan $40 \mathrm{~m}$, di sandaran kiri bendungan terdapat pada kedalaman 13 - 15 m. Sifat fisik batuan tuff mempunyai warna abu-abu hingga coklat tua, sebagian besar batuan lapuk kuat sampai sedang berupa lanau dan lempung, amat liat, serta plastis sedang.

5. Satuan Batuan Residual Soil

Merupakan hasil pelapukan sempurna dari batuan dibawahnya, yaitu batuan vulkanik seperti breksi tuff, tuff lapili, tuff dan aglomerat. Terdapat di puncak bukit pada sandaran kiri dan kanan bendungan, berupa lempung dan lanau yang mengandung gravel, kerakal dan boulder. Dari hasil pengeboran inti ketebalan residual soil antara $4 \mathrm{~m}$ sampai $7 \mathrm{~m}$. 
6. Satuan Batuan Koluvial

Satuan batuan ini merupakan endapan hasil longsoran, yang secara umum merupakan endapan hasil perpindahan material dari suatu tempat ke tempat lain. Satuan batuan ini terdapat di lereng dan kaki perbukitan sebelah kiri dan kanan tumpuan bendungan. Koluvial ini mempunyai ketebalan antara 6,5 m sampai $19 \mathrm{~m}$. Endapan koluvial terdiri dari komponen campuran lempung, lanau, pasir dan gravel sampai boulder, berwarna coklat abu-abu sampai abu-abu, tidak terkonsolidasi.

7. Satuan Batuan Aluvial

Satuan ini tersebar sepanjang dataran banjir kiri dan kanan sungai dan alur sungai. Satuan ini terdiri dari campuran boulder andesit, kerakal, kerikil, pasir dan lanau. Umumnya tidak terkonsolidasi, diendapkan secara tidak selaras diatas batuan tuff. Di alur sungai endapan aluvial memiliki ketebalan 3,3 m.

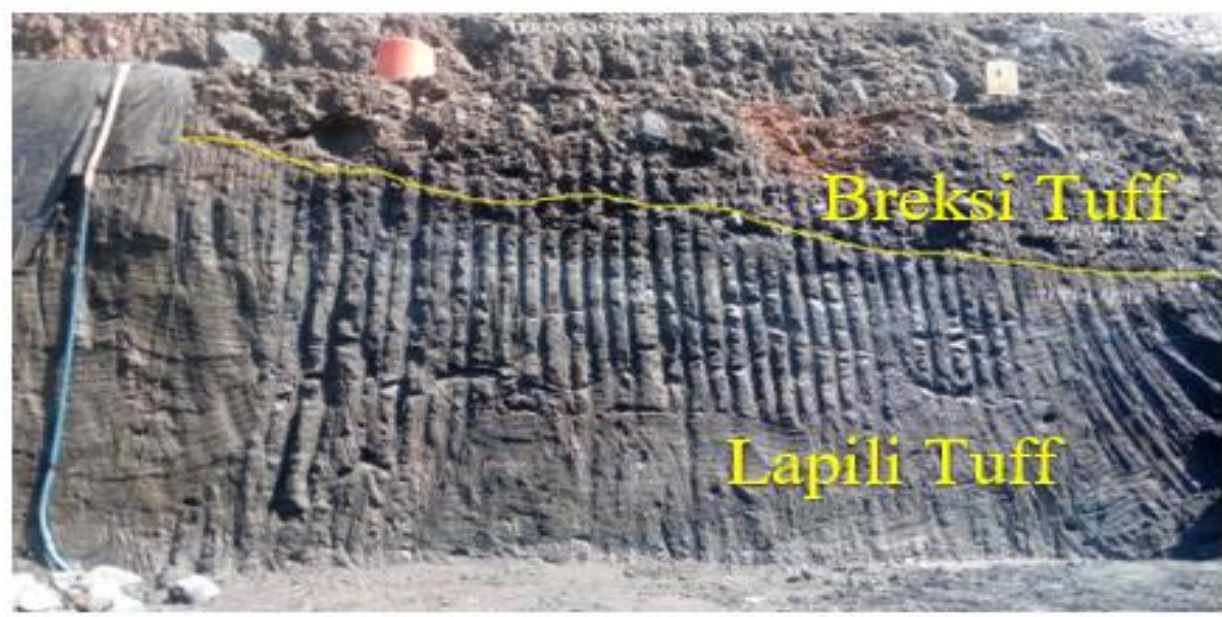

Gambar 1. Satuan batuan beaksi tuff dan lapili tuff pada bukit sandaran kanan

Penampang Tipikal Bendungan

Desain Bendungan Ciawi merupakan bendungan dengan type urgan zonal dengan inti tegak , yang teridiri dari material penyusun berupa zona inti kedap air, zona filter halus,

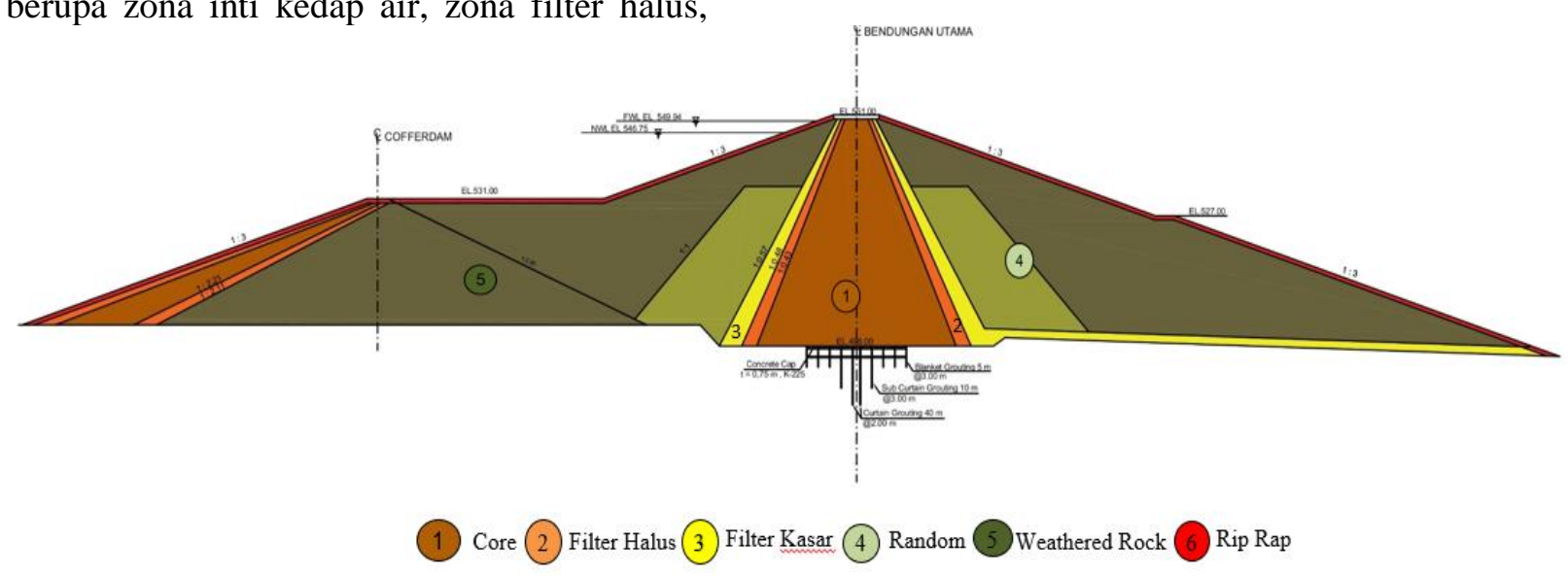

Gambar 2. Tipical Tubuh Bendungan Ciawi

\section{Parameter Desain Bendungan}

Dari hasil analisis perhitungan serta uji laboratorium yang telah dilaksanakan, hasil parameter desain yang dapat digunakan dalam perhitungan stabilitas Bendungan Ciawi dapat dilihat pada tabel 2 
Tabel. 2 Parameter Desain Bendungan Ciawi

\begin{tabular}{|c|c|c|c|c|c|c|c|c|c|}
\hline \multirow{3}{*}{ No } & \multirow{3}{*}{ Parameter } & \multirow{3}{*}{ Unit } & \multicolumn{7}{|c|}{ Material } \\
\hline & & & 1 & 2 & 3 & 4 & 5 & 6 & 7 \\
\hline & & & Inti & $\begin{array}{l}\text { Filter } \\
\text { Halus }\end{array}$ & $\begin{array}{l}\text { Filter } \\
\text { Kasar }\end{array}$ & Random & \begin{tabular}{|c}
$\begin{array}{c}\text { Weathered } \\
\text { Rock }\end{array}$ \\
\end{tabular} & Rip-Rap & Pondasi \\
\hline 1 & $\begin{array}{l}\text { Berat isi } \\
\text { kering }(\gamma d)\end{array}$ & $t / \mathrm{m}^{3}$ & 1,132 & 1,470 & 1,650 & 1,433 & 1,658 & 2,609 & 1,062 \\
\hline 2 & $\begin{array}{l}\text { Berat isi } \\
\text { basah }(\gamma \mathrm{t})\end{array}$ & $\mathrm{t} / \mathrm{m}^{3}$ & 1,621 & 1,617 & 1,820 & 1,787 & 1,989 & 2,634 & 1,278 \\
\hline 3 & $\begin{array}{l}\text { Berat isi jenuh } \\
(\gamma \mathrm{s})\end{array}$ & $t / m^{3}$ & 1,700 & 1,965 & 2,050 & 1,837 & 1,961 & 2,678 & 1,649 \\
\hline & $\begin{array}{l}\text { Sudut geser } \\
\text { dalam }(\phi)\end{array}$ & 。 & 14 & 31 & 33 & 22 & 32 & 35 & 22 \\
\hline 4 & $\begin{array}{l}\text { Sudut geser } \\
\text { dalam efektif } \\
\left(\phi^{\prime}\right)\end{array}$ & $\circ$ & 17 & & & & & & \\
\hline & Kohesi (C) & $t / m^{2}$ & 2,67 & 0,39 & 0,50 & 4,45 & 5,23 & 0,00 & 7,02 \\
\hline 3 & $\begin{array}{l}\text { Kohesi efektif } \\
\left(C^{\prime}\right)\end{array}$ & $t / m^{2}$ & 2,42 & & & & & & \\
\hline 6 & $\begin{array}{l}\text { Koefisien } \\
\text { Permeabilitas }\end{array}$ & $\mathrm{cm} / \mathrm{dt}$ & $6,11 \times 10^{-6}$ & $8,50 \times 10^{-3}$ & $5,14 \times 10^{-2}$ & $2,96 \times 10^{-5}$ & $4,02 \times 10^{-5}$ & $1 \times 10^{-1}$ & $1 \times 10^{-4}$ \\
\hline
\end{tabular}

Sumber : Balai Besar Wilayah Sungai Ciliwung-Cisadane (2016)

\section{Kelas Resiko dan Koefisien Gempa}

Berdasarkan pedoman konstruksi untuk analisis stabilitas bendungan tipe urugan akibat beban gempa dari Departemen Pemukiman Dan Prasarana Wilayah tahun 2004, perhitungan kelas risiko bendungan dapat dilakukan dengan menjumlahkan bobot dari 4 parameter, kemudian dimasukkan ke dalam tabel kelas risiko. Bendungan Ciawi termasuk ke dalam kelas risiko IV (extrem). Hasil klasifikasi kelas risiko kemudian dimasukkan kedalam tabel kriteria beban gempa, sehingga didapatkan kriteria beban gempa OBE perulangan pada $\mathrm{T}=100$ tahun dengan FKmin $\geq 1,20$ sesuai dengan kriteria yang berlaku dan gempa MDE perulangan $\mathrm{T}=$ 10.000 tahun dengan FK $\geq 1$. Perhitungan koefisien gempa membutuhkan nilai percepatan gempa dasar yaitu $\mathrm{OBE}=0,145$ $(\mathrm{T}=100$ tahun $), \mathrm{MDE}=0,630 \quad(\mathrm{~T}=10.000$ tahun), dan faktor amplikasi gempa OBE 1,0 dan MDE 1,0.

Langkah pertama yang dilakukan dalam perhitungan percepatan gempa dasar atau
Operation Base Earthquake (OBE) dan Maximum Design Earthquake (MDE) menggunakan persamaan (1). Diperoleh nilai PGA pada kondisi OBE 0,145 g, dan kondisi MDE 0,630 g., dan untuk selanjutnya dilakukan perhitungan koefisien gempa terkoreksi di permukaan tanah (Ko) pada kondisi OBE dan MDE menggunakan persamaan (2) dan (3). Dari hasil perhitungan didapatkan nilai Ko pada kondisi OBE 0,073, dan kondisi MDE 0,315.

Perhitungan koefisien gempa pada penelitian ini dilakukan pada kedalaman $\mathrm{Y} / \mathrm{H}$ $1 ; 0,75 ; 0,5 ; 0,25$ menggunakan persamaan (3) dan (4). Hasil perhitungan tersebut diperoleh dari nilai koefisien gempa horizontal $(\mathrm{Kh})$ dapat dilihat pada tabel 3. Untuk mencari nilai koefisien gempa vertikal $(\mathrm{Kv})$ dilakukan perhitungan menggunakan Persamaan (6) yang dihitung sebesar 0,6 x Kh dapat dilihat pada tabel 4 . 
Vol. 3 No.2 Juni 2020

http://jurnal.umsb.ac.id/index.php/RANGTEKNIKJOURNAL

Tabel 3 Koefisien Gempa Horizontal OBE dan MDE

\begin{tabular}{ccccccccc}
\hline \multirow{2}{*}{ No } & Periode & Ko & Kh & \multicolumn{4}{c}{ Kh pada y/H } & Keterangan \\
\cline { 2 - 9 } & Ulang $(\mathbf{T})$ & $(\mathbf{g})$ & $(\mathbf{g})$ & $\mathbf{1}$ & $\mathbf{0 . 7 5}$ & $\mathbf{0 . 5}$ & $\mathbf{0 . 2 5}$ & \\
\hline $\mathbf{1}$ & 100 & 0.073 & 0.0365 & 0.102 & 0.112 & 0.123 & 0.148 & OBE \\
\hline $\mathbf{2}$ & 10000 & 0.315 & 0.1575 & 0.441 & 0.488 & 0.536 & 0.642 & MDE \\
\hline
\end{tabular}

Tabel 4 Koefisien Gempa Vertikal OBE dan MDE

\begin{tabular}{|c|c|c|c|c|c|c|c|c|}
\hline \multirow{2}{*}{ No } & \multirow{2}{*}{$\frac{\text { Periode }}{\text { Ulang (T) }}$} & \multirow{2}{*}{$\frac{\text { Ko }}{(g)}$} & \multirow{2}{*}{$\frac{\mathbf{K v}}{(\mathrm{g})}$} & \multicolumn{4}{|c|}{ Kv pada $y / H$} & \multirow[t]{2}{*}{ Keterangan } \\
\hline & & & & 1 & 0.75 & 0.5 & 0.25 & \\
\hline 1 & 100 & 0.044 & 0.022 & 0.061 & 0.067 & 0.074 & 0.089 & OBE \\
\hline 2 & 10000 & 0.189 & 0.095 & 0.265 & 0.293 & 0.322 & 0.385 & MDE \\
\hline
\end{tabular}

Sumber : Hasil perhitungan (2020)

\section{Analisis Kestabilan Lereng}

Dalam analisis kestabilan lereng tubuh Bendungan Ciawi menggunakan Software Geostudio 2012 dengan program Slope/W, pendekatan dengan metode irisan bidang luncur dengan menggunakan metode Simplified Bishop. Analisis dilakukan pada tiga kondisi, yaitu pada kondisi selesai konstruksi, muka air normal, dan rapid drawdown. Data analisis menggunakan parameter desain material yang telah dilakukan uji laboratorium meliputi nilai kohesi (c), sudut geser dalam $(\phi)$, dan berat isi dapat dilihat pada tabel 2. Selain data parameter desain material timbunan, data koefisien gempa digunakan untuk masingmasing kondisi dapat dilihat pada tabel 3 dan tabel 4.

\section{Kondisi Selesai Konstruksi}

Pada kondisi selesai konstruksi, pada umumnya bendungan masih kering dan belum ada genangan air. Maka pada kondisi ini diasumsikan bahwa material timbunan bersifat kering sehingga berat jenis yang digunakan adalah berat jenis kering $\left(\gamma_{\text {dry }}\right)$. Pada kondisi ini dibagi menjadi kondisi tanpa gempa dan dengan gempa pada bagian hulu dan hilir. Hasil perhitungan FK tanpa ada gempa pada kondisi selesai konstruksi dapat dilihat pada tabel 5 dan kondisi ada gempa OBE pada tabel 6 dan gempa MDE setelah selesai konstruksi dapat dilihat pada tabel 7 .

\section{Kondisi Muka Air Total}

Pada kondisi muka air total, bendungan sudah memasuki tahap operasional dan digenangi air. Muka air normal pada Bendungan Ciawi direncanakan berada pada elevasi di 546,75 mdpl. Pada kondisi ini, diasusmsikan material bersifat jenuh air sehingga berat jenis yang digunakan yaitu berat jenis jenuh $\left(\gamma_{\text {sat }}\right)$. Hasil perhitungan FK pada kondisi muka air normal dapat dilihat pada Tabel 6 .

\section{Kondisi Rapid Drawdown}

Pada kondisi rapid drawdown, kondisi muka air berubah dari kondisi muka air normal (546,75 mdpl) ke muka air minimum $(501,00$ mdpl). Pada kondisi ini, diasusmsikan material bersifat jenuh air sehingga berat jenis yang digunakan yaitu berat jenis jenuh $\left(\gamma_{\text {sat }}\right)$. Pada kondisi ini, digunakan dua buah garis freatik untuk menggambarkan kondisi awal dan kondisi akhir. Garis freatik pada muka air minimum mengikuti garis freatik pada kondisi muka air normal. Hasil perhitungan FK pada kondisi tanpa gempa dapat dilihat pada tabel 5, untuk kondisi gempa OBE dan MDE dapat dilihat pada tabel 6 dan tabel 7 serta permodelannya dapat dilihat pada gambar 3, 4 dan 5 . 


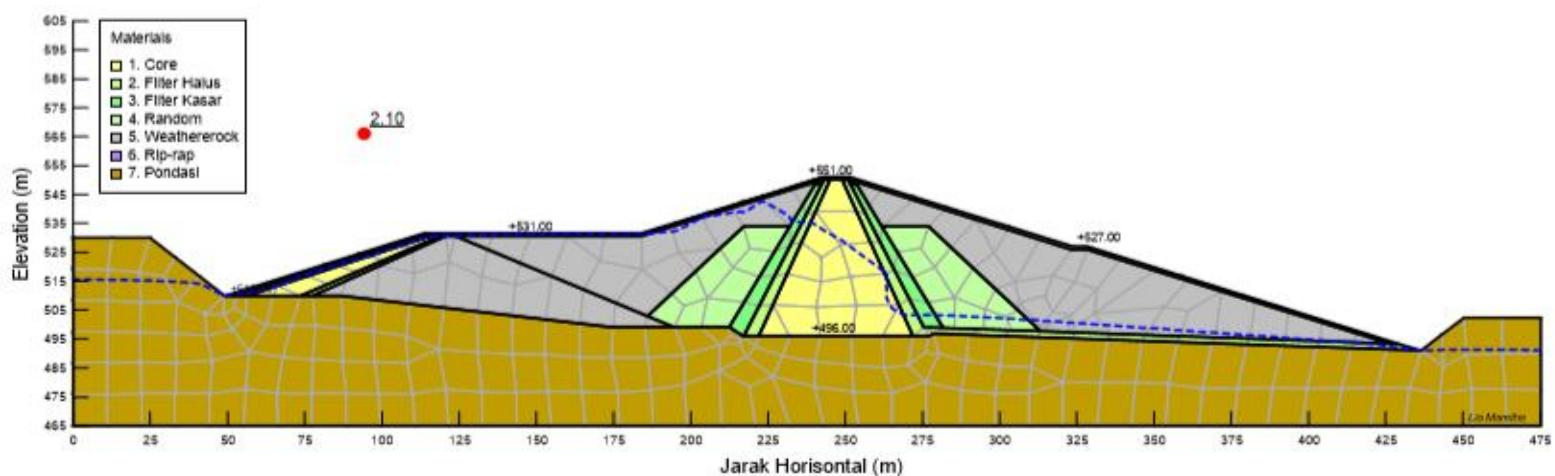

Gambar 3. Analisis Dinamis Tanpa Ada Gempa, Stabilitas Lereng Hulu Bendungan, Kondisi Rapid Drawdown

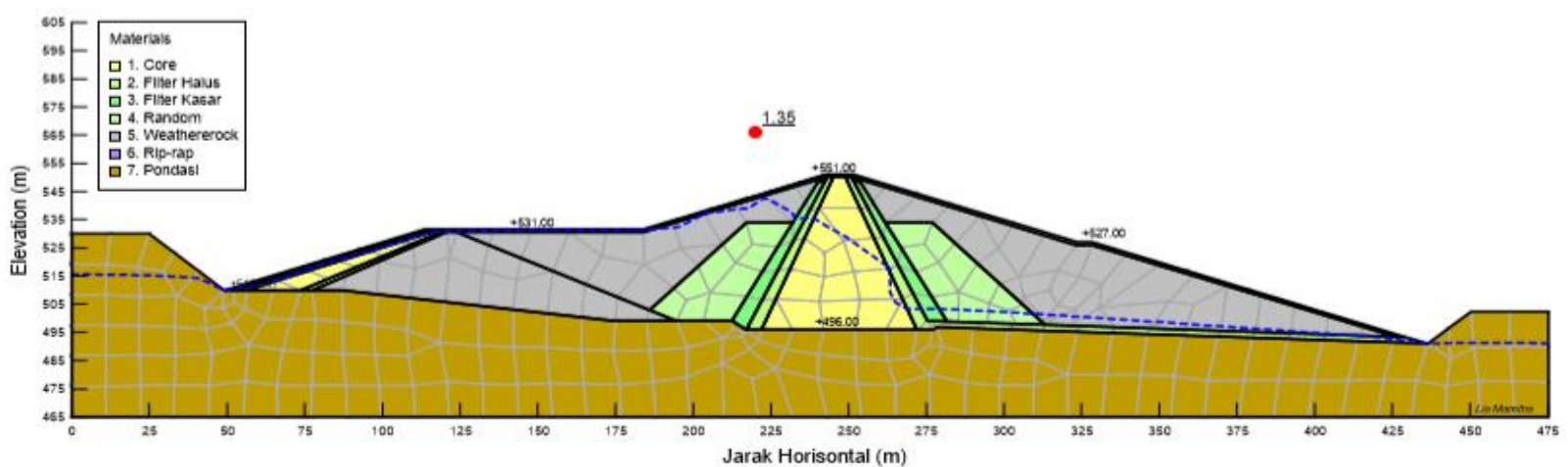

Gambar 4. Analisis Dinamis (Gempa OBE) Stabilitas Lereng Hulu Bendungan, Kondisi Rapid Drawdown $\mathrm{y} / \mathrm{H}=$ 0,25

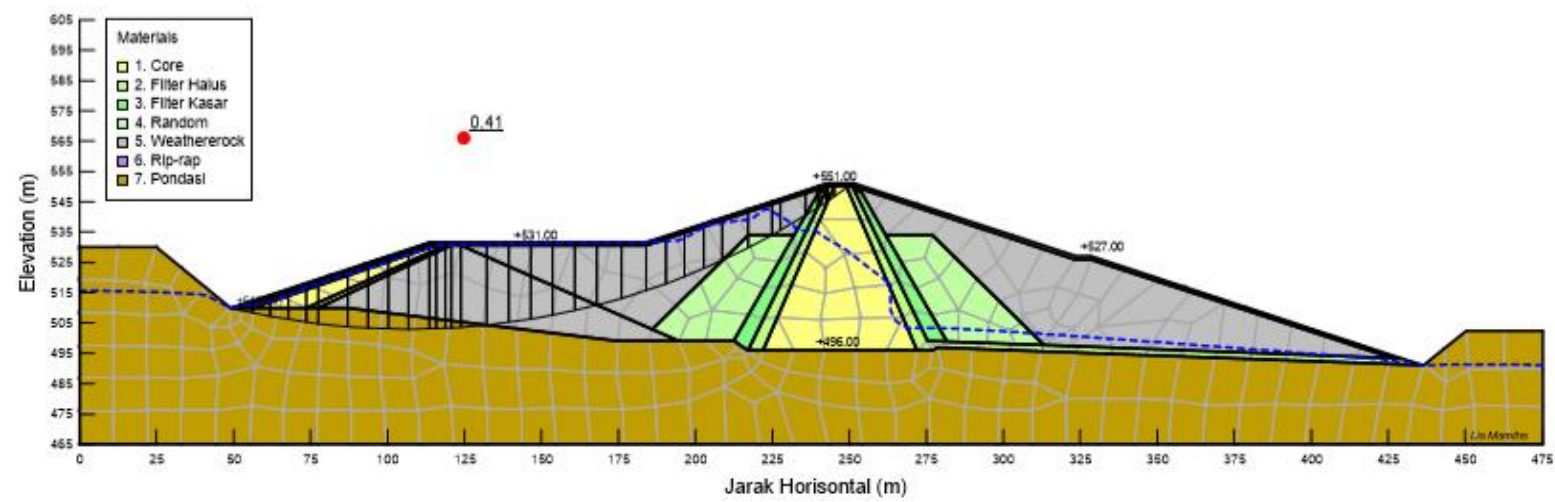

Gambar 5. Analisis Dinamis (Gempa MDE) Stabilitas Lereng Hulu Bendungan, Kondisi Rapid Drawdown $\mathrm{NWL}+546,50, \mathrm{y} / \mathrm{H}=0,75$

Berdasarkan hasil analisis yang telah dilakukan, dapat diketahui nilai faktor keamanan pada masing-masing kondisi berdasarkan tabel 5, 6, dan 7 menunjukkan bahwa desain Bendungan Ciawi (Dry Dam) pada kondisi tanpa gempa dan kondisi gempa OBE termasuk dalam kategori aman, tetapi untuk kondisi gempa MDE terjadi longsoran pada sisi hulu sehingga kondisi bendungan menjadi tidak aman. Dari hasil ini, perlu dilakukan studi lebih lanjut, tidak hanya melakukan analisis dinamik dengan metode psidostatik tetapi dapat dilakukan dengan metode lain misalnya metode newmark sliding analysis atau analisis numerik. Sedangkan untuk kondisi rapid drawdown sebaiknya dilakukan analisis pada kondisi aliran transient, mengingat fungsi bendungan Ciawi sebagai detention dam yang memiliki kondisi muka air yang tidak tetap. 
Vol. 3 No.2 Juni 2020

http://jurnal.umsb.ac.id/index.php/RANGTEKNIKJOURNAL

Tabel 5 Hasil Analisis Statis Stabilitas Lereng Bedungan Ciawi (Dry Dam) Tanpa Ada Gempa

Kondisi

Tanpa Gempa

\begin{tabular}{lllc}
\cline { 2 - 3 } \multirow{2}{*}{$\begin{array}{l}\text { After } \\
\text { Construction }\end{array}$} & FK & FK Syarat \\
\cline { 2 - 3 } Muka Air Normal & Hilir & 2.10 & \multirow{2}{*}{1.30} \\
\cline { 2 - 3 } & Hulu & 2.05 & 1.50 \\
\cline { 2 - 3 } Rapid Drawdown & Hulu & 1.80 & \multirow{2}{*}{1.30} \\
\cline { 2 - 3 } & Hilir & 2.10 & \\
\hline
\end{tabular}

Tabel 6. Hasil Analisis Dinamis Stabilitas Bendungan Ciawi (Dry Dam) Dengan Beban Gempa OBE

OBE

\begin{tabular}{|c|c|c|c|c|c|c|}
\hline \multicolumn{2}{|l|}{ Kondisi } & \multirow{2}{*}{$\begin{array}{c}\mathrm{y} / \mathrm{H}=1 \\
\mathrm{Kh}=\mathbf{0 . 1 0 2 g}\end{array}$} & \multirow{2}{*}{$\begin{array}{c}\mathrm{y} / \mathrm{H}=0.75 \\
\mathrm{Kh}=0.112 \mathrm{~g}\end{array}$} & \multirow{2}{*}{$\begin{array}{c}\mathrm{y} / \mathrm{H}=\mathbf{0 . 5 0} \\
\mathrm{Kh}=\mathbf{0 . 1 2 3 g}\end{array}$} & \multirow{2}{*}{$\begin{array}{c}\mathrm{y} / \mathrm{H}=0.25 \\
\mathrm{Kh}=0.148 \mathrm{~g}\end{array}$} & \multirow{3}{*}{$\begin{array}{c}\text { FK } \\
\text { Syarat }\end{array}$} \\
\hline & & & & & & \\
\hline & & $\mathrm{Kv}=0.061 \mathrm{~g}$ & $K v=0.067 \mathrm{~g}$ & $\mathrm{Kv}=0.074 \mathrm{~g}$ & $\mathrm{Kv}=0.089 \mathrm{~g}$ & \\
\hline \multirow{2}{*}{ After Contruction } & Hulu & 2.36 & 2.27 & 3.07 & 1.35 & \multirow{2}{*}{1.20} \\
\hline & Hilir & 1.57 & 1.97 & 2.00 & 1.35 & \\
\hline \multirow{2}{*}{ Muka Air Normal } & Hulu & 2.15 & 2.03 & 2.67 & 1.01 & \multirow{2}{*}{1.20} \\
\hline & Hilir & 1.40 & 1.90 & 2.00 & 1.35 & \\
\hline \multirow{2}{*}{ Rapid Drawdown } & Hulu & 1.30 & 1.25 & 1.72 & 1.35 & \multirow{2}{*}{-} \\
\hline & Hilir & 1.40 & 1.90 & 2.00 & 1.35 & \\
\hline
\end{tabular}

Tabel 7. Hasil Analisis Dinamis Stabilitas Bendungan Ciawi (Dry Dam) dengan Beban Gempa MDE

MDE

\begin{tabular}{|c|c|c|c|c|c|c|}
\hline \multirow[t]{3}{*}{ Kondisi } & & $\mathbf{y} / \mathbf{H}=\mathbf{1}$ & $\mathbf{y} / \mathbf{H}=\mathbf{0 . 7 5}$ & $\mathbf{y} / \mathbf{H}=\mathbf{0 . 5 0}$ & $\mathrm{y} / \mathrm{H}=\mathbf{0 . 2 5}$ & \multirow[t]{3}{*}{$\begin{array}{c}\text { FK } \\
\text { Syarat }\end{array}$} \\
\hline & & $\mathrm{Kh}=0.441 \mathrm{~g}$ & $\mathrm{Kh}=0.488 \mathrm{~g}$ & $\mathrm{Kh}=0.536 \mathrm{~g}$ & $K h=0.642 g$ & \\
\hline & & $K v=0.265 g$ & $\mathrm{Kv}=0.293 \mathrm{~g}$ & $\mathrm{Kv}=0.322 \mathrm{~g}$ & $K v=0.385 g$ & \\
\hline \multirow{2}{*}{ After Contruction } & Hulu & 0,94 & 0,86 & 1.06 & 0.38 & \multirow{2}{*}{1.00} \\
\hline & Hilir & 0,76 & 0,91 & 0.93 & 0.38 & \\
\hline \multirow{2}{*}{ Muka Air Normal } & Hulu & 0.64 & 0.57 & 0.72 & 0.90 & \multirow{2}{*}{1.00} \\
\hline & Hilir & 0.66 & 0.80 & 0.93 & 0.38 & \\
\hline \multirow{2}{*}{ Rapid Drawdown } & Hulu & 0,47 & 0.41 & 0.53 & 0.38 & \\
\hline & Hilir & 0.67 & 0.91 & 0.93 & 0.38 & \\
\hline
\end{tabular}

Pada bagian hulu dan hilir, kestabilan lereng saat kondisi tanpa beban gempa menunjukkan nilai faktor keamanan relatif tinggi dibanding kondisi pada saat beban gempa OBE maupun MDE. Hal ini disebabkan pada kondisi tanpa beban gempa material urugan dari tubuh bendungan relatif stabil terhadap tekanan dan tegangan dari gaya yang di hasilkan oleh getaran gempa. Sehingga kondisi beban gempa
OBE dan MDE akan memiliki nilai faktor keamanan yang lebih kecil. Selain itu, pada bagian hilir kondisi tanpa beban gempa maupun dengan beban gempa OBE dan MDE memiliki nilai $\mathrm{Fk}$ yang relatif lebih kecil dibandingkan bagian hulu. Hal ini dikarenakan pada bagian hilir bendungan memiliki tekanan yang tinggi pada saat volume muka air bendungan bertambah. Hal ini juga disebabkan 
oleh material tanggul yang jenuh air sehingga berat jenisnya semakin bertambah, sehingga kestabilan lereng bagian hilir semakin berkurang.

Berdasarkan hasil analisis kestabilan lereng yang sudah dilakukan nilai faktor keamanan (FK) hasil perhitungan pada kondisi tanpa gempa dan dengan kondisi gempa OBE nilai FK telah memenuhi syarat, namun pada kondisi Gempa MDE tidak memenuhi FK minimum standar SNI 8064:2016, sehingga perlu dilakukan penelitian selanjutnya dengan modifikasi geometri lereng dan zona typical pada bendungan serta dengan analisis dinamik dengan metode yang lainnya (Kramer, 1996).

\section{PENUTUP}

Berdasarkan pembahasan di atas dapat diambil beberapa kesimpulan yaitu :

1. Lokasi penelitian tersusun atas 7 (tujuh) satuan batuan yaitu Satuan batuan Breaksi Tuff, Aglomerate, Tuff Lapili, Tuff, Residual Soil, Koluvial, dan Aluvial.

2. Bendungan Ciawi merupakan bendungan urugan dengan tipe zonal yang terdiri dari inti, filter halus, filter kasar, random, Weathered Rock dan rip-rap sehingga setiap zona memiliki nilai berat jenis, kohesi dan sudut geser dalam yang beragam.

3. Nilai faktor keamanan (FK) hasil perhitungan pada kondisi tanpa gempa dan gempa OBE telah memenuhi FK minimum tetapi untuk kondisi gempa MDE tidak memenuhi FK minimum standar standar SNI 8064:2016.

\section{UCAPAN TERIMA KASIH}

Penulis mengucapkan terimakasih kepada seluruh pihak yang telah membantu dalam penulisan ini yakni dari Balai Wilayah Sungai (BBWS) Ciliwung-Cisadane.

\section{DAFTAR PUSTAKA}

Balai Besar Wilayah Sungai CiliwungCisadane. (2016). Laporan Akhir Bendungan Ciawi. Jakarta.

Chopra, A. K. (1995). Theory and Applications to Earthquake Engineering. New Jersey: Prentice - Hall.

Departemen Pemukiman Dan Prasarana Wilayah. (2004). Analisis Stabilitas Bendungan Tipe Urugan Akibat Beban
Gempa.

Dharmayasa, I. G. N. P., Redana, I. W., \& Suwarsa Putra, T. G. (2017). Analisis Keamanan Lereng Bendungan Utama Pada Bendungan Benel Di Kabupaten Jembrana. Jurnal Spektran, 2(2), 68-77. https://doi.org/10.24843/spektran.2014.v 02.i02.p09

Direktorat Jenderal Sumber Daya Air. (2003). Pedoman Kriteria Umum Desain Bendungan. Jakarta: Komisi Keamanan Bendungan.

Fata, Y. A., \& Suhartanto, E. (2018). Analisis Stabilitas Lereng Bendungan Sutami Berdasarkan Peta Gempa 2017. Jurnal Mahasiswa Jurusan Teknik Pengairan, 1. Imron, A., Sarah, D., Hardiyati, S., \& Sadono, K. W. (2017). Analisa Geoteknik Bendungan Gongseng Terhadap. Jurnal Karya Teknik Sipil, 6, 83-90.

Kramer, S. L. (1996). Geothechnical Earthquake Engineering. Upper Saddle River,New Jersey 07458.

Nanda, T. N. F., \& Hamdhan, I. N. (2016). Analisis Rembesan dan Stabilitas Bendungan Bajulmati dengan Metode Elemen Hingga Model 2D dan 3D. Journal Reka Racana, 2(4).

SNI 8064-2016. (2016). Metode analisis stabilitas lereng statik bendungan tipe urugan. Jakarta: Badan Standarisasi Nasional.

Soedibyo. (2003). Teknik Bendungan. Jakarta: Pradnya Paramita.

Tanjung, M. I., Sari, R. N., \& Ghafara, R. (2018). Screening analysis stabilitas lereng bendungan urugan akibat gempa di Indonesia. Jurnal Teknik Hidraulik, $8(1), 43-56$. 